\title{
Autoimmune Destruction of Pancreatic $\beta$ Cells
}

\author{
Ji-Won Yoon* and Hee-Sook Jun
}

Type 1 diabetes results from the destruction of insulin-producing pancreatic $\beta$ cells by a $\beta$ cell-specific autoimmune process. $\beta$ Cell autoantigens, macrophages, dendritic cells, B lymphocytes, and T lymphocytes have been shown to be involved in the pathogenesis of autoimmune diabetes. $\beta$ Cell autoantigens are thought to be released from $\beta$ cells by cellular turnover or damage and are processed and presented to $T$ helper cells by antigen-presenting cells. Macrophages and dendritic cells are the first cell types to infiltrate the pancreatic islets. Naive $\mathrm{CD} 4^{+} \mathrm{T}$ cells that circulate in the blood and lymphoid organs, including the pancreatic lymph nodes, may recognize major histocompatibility complex and $\beta$ cell peptides presented by dendritic cells and macrophages in the islets. These $\mathrm{CD}^{+} \mathrm{T}$ cells can be activated by interleukin (IL)-12 released from macrophages and dendritic cells. While this process takes place, $\beta$ cell antigen-specific $\mathrm{CD} 8^{+} \mathrm{T}$ cells are activated by IL-2 produced by the activated $\mathrm{T}_{\mathrm{H}} 1 \mathrm{CD} 4^{+}$ Tcells, differentiate into cytotoxic T cells and are recruited into the pancreatic islets. These activated $\mathrm{T}_{\mathrm{H}} 1$ $\mathrm{CD}^{+} \mathrm{T}$ cells and $\mathrm{CD} 8^{+}$cytotoxic T cells are involved in the destruction of $\beta$ cells. In addition, $\beta$ cells can also be damaged by granzymes and perforin released from $\mathrm{CD} 8^{+}$cytotoxic $\mathrm{T}$ cells and by soluble mediators such as cytokines and reactive oxygen molecules released from activated macrophages in the islets. Thus, activated macrophages, $\mathrm{T}_{\mathrm{H}} 1 \mathrm{CD}^{+} \mathrm{T}$ cells, and $\beta$ cell-cytotoxic $\mathrm{CD} 8^{+} \mathrm{T}$ cells act synergistically to destroy $\beta$ cells, resulting in autoimmune type 1 diabetes.

Keywords: autoimmune diabetes, destruction of $\beta$ cells, $\beta$ cell autoantigens, T cells, macrophages/dendritic cells

\section{INTRODUCTION}

Type 1 diabetes results from insulin deficiency caused by the loss of insulin-producing pancreatic $\beta$ cells, ${ }^{1-3}$ generally develops in the young, and accounts for approximately $5 \%-10 \%$ of the diabetic population worldwide. The development of type 1 diabetes is the consequence of progressive $\beta$ cell destruction by autoimmune processes during an asymptomatic period that often extends over many years. Genetic susceptibility is believed to be a prerequisite for the development of type 1 diabetes. ${ }^{4,5}$ However, studies on the development of the disease in identical twins

Rosalind Franklin Comprehensive Diabetes Center, Department of Pathology, Chicago Medical School, North Chicago, IL.

*Address for correspondence: Rosalind Franklin Comprehensive Diabetes Center, Chicago Medical School, 3333 Green Bay Road, North Chicago, IL 60064. E-mail: ji-won.yoon@rosalindfranklin.edu

1075-2765 @ 2005 Lippincott Williams \& Wilkins showed that their concordance rate is only $40 \%$, suggesting that environmental or nongenetic factors contribute to the development of the disease. Histologic analysis of the pancreas from patients with recent-onset type 1 diabetes revealed an infiltration of the islets of Langerhans by mononuclear cells, ${ }^{7}$ which were later identified as $\mathrm{T}$ and $\mathrm{B}$ lymphocytes, monocytes/macrophages, and natural killer (NK) cells. ${ }^{8,9}$ As well, circulating islet-reactive autoantibodies ${ }^{10}$ and islet-reactive $\mathrm{T}$ cells have been found in patients with type 1 diabetes. ${ }^{11-14}$

The pathogenesis of autoimmune type 1 diabetes has been extensively studied using 2 animal models, the nonobese diabetic (NOD) mouse and the diabetesprone BioBreeding (DP-BB) rat, which have greatly enhanced our understanding of the pathogenesis of human type 1 diabetes. Although the exact mechanisms involved in the initiation and progression of $\beta$ cell destruction are still not clear, it is generally believed that $\beta$ cell autoantigens, macrophages, dendritic 
cells, B lymphocytes, and T lymphocytes are involved in the $\beta$ cell-specific autoimmune process. ${ }^{15-19} \beta$ Cell autoantigens are processed by macrophages, dendritic cells, or B cells in the pancreatic islets and presented to autoreactive $\mathrm{CD}^{+} \mathrm{T}$ cells in the peripheral lymphoid system. These autoreactive $\mathrm{CD} 4^{+} \mathrm{T}$ cells are activated and secrete cytokines, which can activate $\beta$ cell-specific cytotoxic $\mathrm{CD}^{+} \mathrm{T}$ cells. The activated $\mathrm{T}$ cells are recruited to the pancreatic islets and produce cytokines, which further activate macrophages and other T cells, contributing to the destruction of $\beta$ cells (Fig. 1). In this review, we briefly discuss the possible roles of islet cell autoantigens, macrophages, and T cells in the autoimmune destruction of pancreatic $\beta$ cells.

\section{ISLET CELL AUTOANTIGENS}

Pancreatic $\beta$ cell autoantigens are the targets of immunemediated destruction of $\beta$ cells. Therefore, antigenspecific immune reactions are believed to be involved in the $\beta$ cell destruction. One of the most common immunologic markers of humans and animals with autoimmune diabetes is the presence of autoantibodies and autoreactive T cells directed against $\beta$ cell autoantigens. These autoantigens include insulin, ${ }^{20}$ glutamic acid decarboxylase (GAD) $65,{ }^{21}$ tyrosine phosphatase, insulinoma antigen (IA)-2 and IA- $2 \beta^{22,23}$ carboxypeptidase- $\mathrm{H}^{24}$ islet cell antigen (ICA)-69, ${ }^{25}$ GM gangliosides, ${ }^{26}$ a $38-\mathrm{kd}$ autoantigen, ${ }^{27}$ and SOX13. ${ }^{28}$ Autoantibodies against these $\beta$ cell autoantigens are not believed to have a pathogenic role. However, the risk of developing diabetes is strongly related to the number of autoantibody markers, that is, the presence of 2 or more autoantibodies gives a higher probability of developing the disease than the presence of a single autoantibody. ${ }^{29}$

\section{Glutamic acid decarboxylase (GAD)}

GAD, which is a synthetic enzyme of the inhibitory neurotransmitter $\gamma$-aminobutyric acid, has been the most extensively studied $\beta$ cell autoantigen. Sera from type 1 diabetic patients was found to precipitate a 64kd protein, which was later identified as GAD. GAD65 antibody is found in $70 \%-75 \%$ of type 1 diabetes patients and $1 \%-2 \%$ of healthy individuals. ${ }^{30}$ The antiGAD autoantibodies in type 1 diabetes patients are predominantly directed to a conformational epitope of

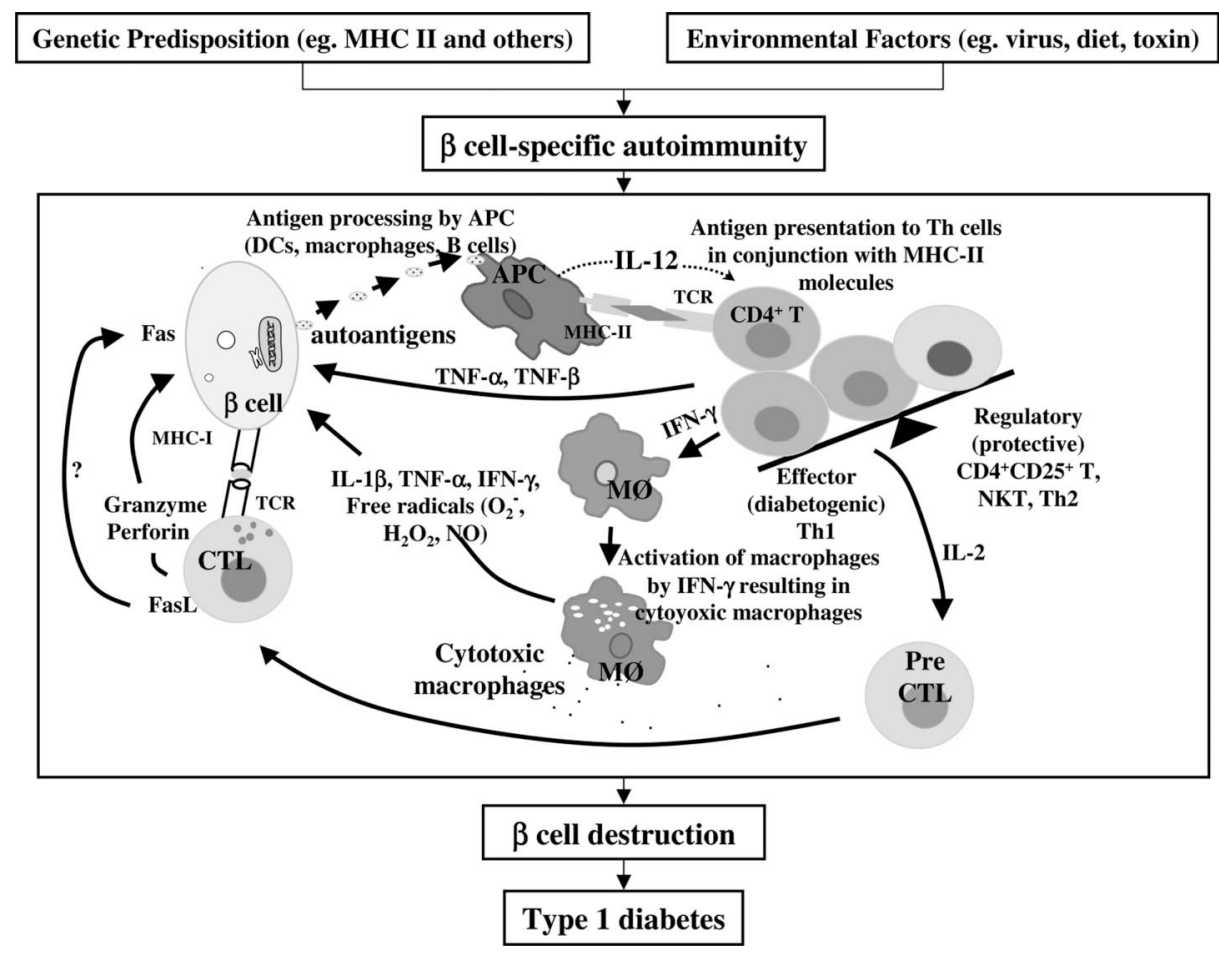

FIGURE 1. Etiology of type 1 diabetes. Genetic predisposition appears to be a prerequisite for the development of type 1 diabetes. Environmental factors such as viruses, toxins, and diet may be involved in the clinical expression of genetic susceptibility. Once $\beta$ cellspecific autoimmunity has developed, autoimmune-mediated destruction of $\beta$ cells results in the onset of type 1 diabetes. Autoantigens released from $\beta$ cells are processed by antigen-presenting cells (APCs) and presented to helper $T$ cells (Th cells) in association with $\mathrm{MHC}$ class II molecules. IL-12 released from APCs activates $T_{H} 1$ type $\mathrm{CD} 4^{+} \mathrm{T}$ cells, causing the immune balance between effector and regulatory cells to breakdown. $\mathrm{T}_{\mathrm{H}} 1$ cells produce IL-2, which activates $\beta$ cell-specific precytotoxic T cells (Pre CTL) to become cytotoxic (CTL), and IFN- $\gamma$, which may cause macrophages (MØ) to become cytotoxic. These cytotoxic macrophages release $\beta$ cell-cytotoxic cytokines including IL-1 $\beta$, TNF- $\alpha$, and IFN- $\gamma$, and free radicals. $\mathrm{T}_{\mathrm{H}} 1$ cells also secrete cytokines that are directly cytotoxic to $\beta$ cells. $\beta$ Cell antigenspecific $\mathrm{CD} 8^{+}$cytotoxic T cells (CTL) recognize antigens expressed on $\beta$ cells in association with MHC class I molecules. These CTLs release granzyme and perforin (cytolysin), which are toxic to $\beta$ cells. In addition, Fas- and TNFR-mediated apoptosis are involved in $\beta$ cell destruction. In this way, macrophages, T cells, and cytokines synergistically act to destroy $\beta$ cells, resulting in the development of autoimmune type 1 diabetes. 
GAD, and the major antigenic region in humans has been identified as the middle and carboxyterminal region of GAD65. ${ }^{31,32}$

Although the presence of anti-GAD65 antibodies is a highly predictive marker for the development of type 1 diabetes in humans, contradictory results have been reported regarding the correlation between the presence of anti-GAD antibodies and diabetes in NOD mice. One study found that anti-GAD65 antibodies were detected in the early stages of the disease, ${ }^{33}$ whereas another study found that the presence of antiGAD65 antibodies was not a prerequisite for the development of diabetes in NOD/Lt and NOD/Wehi mice, which have a higher and lower incidence of diabetes, respectively, than NOD mice. ${ }^{34}$ The latter study suggested that a strong humoral response to GAD may actually be associated with less destructive pathology, as indicated by the negative correlation between insulitis and anti-GAD antibody levels.

It was found that the initial immune response directed against pancreatic islets in NOD mice is a $\mathrm{T}_{\mathrm{H}} 1$ response against a confined region of GAD (amino acids 509-528 and 524-543) and that later responses are directed against another region of GAD and other autoantigens. ${ }^{35}$ Immunization of NOD mice with purified GAD resulted in the tolerization of GAD-reactive T cells and blocked the $\mathrm{T}$ cell response to other $\beta$ cell antigens, thus preventing diabetes. ${ }^{35}$ There is also direct evidence that GAD-reactive T cells are diabetogenic in NOD mice. ${ }^{36,37}$ GAD-specific $\mathrm{CD}^{+} \mathrm{T}$ cells have also been observed in recent-onset type 1 diabetic patients and their relatives at risk to develop diabetes. ${ }^{38-40}$ In addition to $\mathrm{CD} 4^{+}$ T cells, MHC class I human lymphocyte antigen (HLA)$\mathrm{A}^{*} 0201$-restricted $\mathrm{CD} 8^{+}$cytotoxic $\mathrm{T}$ cells reactive against GAD were identified in recently diagnosed diabetic patients and in high-risk subjects, but not in healthy control subjects expressing HLA-A ${ }^{*} 0201{ }^{41}$ These results suggest that GAD may be an important target antigen and GAD-reactive T cells may play a pathogenic role in the destruction of pancreatic $\beta$ cells in animal models and in human type 1 diabetes. However, contradictory results regarding the role of GAD in the pathogenesis of type 1 diabetes have been reported. Some GAD-reactive $\mathrm{T}$ cells do not have the ability to induce diabetes, and Tcell responses to GAD-derived peptides were observed in mice resistant to type 1 diabetes, ${ }^{42,43}$ suggesting that peripheral tolerance to GAD is not associated with protection from diabetes. In addition, molecular mimicry between GAD and Coxsackie B4 virus has been hypothesized for the development of type 1 diabetes, but controversies still exist. ${ }^{44,45}$

To investigate the role of GAD in the pathogenesis of autoimmune diabetes, several lines of transgenic mice have been established in which the expression of GAD has been manipulated. Hyperexpression of GAD65 in $\beta$ cells of NOD mice resulted in a lower incidence of diabetes in one line of transgenic mice and no difference in the incidence of diabetes in another transgenic line, as compared with nontransgenic control NOD mice. A quantitative difference in the expression of GAD between the 2 lines might have accounted for prevention of diabetes. ${ }^{46} \mathrm{~A}$ transgenic NOD mouse line that expresses GAD65 in all tissues showed an accelerated onset and increased incidence of diabetes as compared with control NOD mice. ${ }^{47}$ Interestingly, $\beta$ cell-specific suppression of GAD65 and GAD67 expression prevented insulitis and diabetes in antisense-GAD transgenic mice backcrossed with NOD mice. ${ }^{48,49}$ These results suggest that the expression of GAD in pancreatic $\beta$ cells is involved in the modulation of $\beta$ cell-specific autoimmunity. Recently, it was reported that expression of a modified form of GAD under the control of the invariant chain promoter in NOD mice induced tolerance to GAD65, but failed to prevent insulitis and diabetes, ${ }^{50}$ suggesting that inhibition of the generation of GAD65-reactive T cells may not be the mechanism for the prevention of diabetes in GAD-suppressed NOD mice. However, GAD67-reactive T cells were not tolerized in this study. Because GAD67 is the dominant form in mice and any level of GAD expression in NOD mice results in the development of diabetes, further study on the tolerization of both GAD65 and GAD67-reactive T cells remains to be done to determine the precise role of GAD-reactive T cells in the development of diabetes.

Another possibility regarding the prevention of $\beta$ cell destruction in GAD-suppressed NOD mice is that suppression of GAD in $\beta$ cells may have rendered the $\beta$ cells more resistant to destruction by T cells and/or macrophages because normal $\beta$ cells expressing GAD show expression of tissue transglutaminase, which is known to promote apoptosis of cells, whereas tissue transglutaminase is suppressed in GAD-suppressed $\beta$ cells. A further possibility is that a diabetes-resistant gene from the strain of origin might have been transmitted to the transgenic offspring, as these antisense GAD transgenic mice were produced using eggs from $(\mathrm{SJL} \times \mathrm{C} 57 \mathrm{BL} / 6) \mathrm{F} 2$ mice, which are diabetes resistant. Systemic GAD65 knockout mice backcrossed with NOD mice for 4 generations still developed diabetes and insulitis similar to wild-type NOD mice. ${ }^{51}$ However, it is difficult to draw any definite conclusions from this study, as mouse $\beta$ cells predominantly express GAD67 and very low levels of GAD65, and these GAD65 knockout mice still express GAD67. Therefore, $\beta$ cell-specific conditional GAD65/67 knockout NOD mice are essential to find whether the expression of GAD in $\beta$ cells truly plays 
a critical role in the initiation of $\beta$ cell-specific autoimmune diabetes.

\section{Insulin}

Insulin was the first diabetes-related autoantigen to be discovered. Autoantibodies to insulin are found in $50 \%-70 \%$ of type 1 diabetic children ${ }^{52}$ and are the first sign of an ongoing autoimmune process. ${ }^{53}$ It was also reported that the early appearance of insulin autoantibody predicts early development of diabetes in NOD mice. ${ }^{54}$ Insulin B chain-specific $\mathrm{CD}^{+}{ }^{+}$cell clones accelerate diabetes in NOD.scid mice. ${ }^{55}$ Transgenic expression of mouse proinsulin II under a MHC class II gene promoter prevented the development of diabetes in NOD mice. ${ }^{56}$ These results suggest that insulin autoantigen plays an important role in the development of type 1 diabetes. However, the pathogenic role of insulin autoantibody and insulin-reactive $\mathrm{T}$ cells needs further investigation.

\section{IA-2/IA-2 $\beta$}

IA-2 and IA- $2 \beta$ are newly discovered members of the protein tyrosine phosphatase family and are considered to be major autoantigens of type 1 diabetes. Initially, autoantibodies directed against a 37/40-kd tryptic fragment were detected in sera of type 1 diabetes patients. ${ }^{57}$ Later, IA-2 was identified as the precursor of the 40-kd fragment, ${ }^{22,58}$ and IA-2 $\beta$ (also known as phogrin) was identified as the precursor of the $37-\mathrm{kd}$ fragment. ${ }^{23,59}$ IA-2 and IA-2 $\beta$ have a high degree of homology and are located in secretory granules, but the role of these molecules in $\beta$ cells is not clear. Autoantibodies to IA- 2 are present in $70 \%-80 \%$ of type 1 diabetic children, ${ }^{60}$ making them useful serological markers for human type 1 diabetes. In addition, $\mathrm{T}$ cells from diabetic patients respond to IA-2 antigen. ${ }^{11,12}$ However, the precise role of the IA- 2 and IA- $2 \beta$ antigens in the pathogenesis of type 1 diabetes is unknown.

\section{MACROPHAGES}

Macrophages and dendritic cells are among the first cell types to infiltrate the pancreatic islets during the disease process in NOD mice and BB rats. ${ }^{61-63}$ This infiltration precedes invasion of the islets by $\mathrm{T}$ lymphocytes, NK cells, and B lymphocytes. ${ }^{64}$ It was reported that $B$ cells also play an important role as antigenpresenting cells (APCs) for $\beta$ cell antigens in the process of the development of $\beta$ cell-specific autoimmunity in NOD mice. ${ }^{65}$ The activation of $\beta$ cell-reactive T cells may be initiated from the processing and presentation of $\beta$ cell autoantigens by APCs in the pancreatic islets. APCs that present $\beta$ cell autoantigenic peptides in conjunction with MHC molecules migrate to the pancreatic lymph nodes where they are recognized by circulating naive $\beta$ cell-autoreactive T cells. The naive $\mathrm{T}$ cells are then activated, migrate to the pancreatic islets, and are further activated by re-encountering the cognate $\beta$ cell antigens (Fig. 2).

Inactivation of macrophages in NOD mice or BB rats significantly prevented the development of diabetes. ${ }^{66-68}$ Further studies showed that macrophages are required for the development of effector T cells that destroy $\beta$ cells in NOD mice ${ }^{69}$ (Fig. 3). T cells in macrophagedepleted NOD mouse recipients did not destroy transplanted NOD islets, indicating that T cells in a macrophage-depleted environment lose their ability to differentiate into cytotoxic T cells. The level of IL-4 secreted from $\mathrm{T}_{\mathrm{H}} 2$ cells was increased, whereas the level of IFN- $\gamma$ secreted from $\mathrm{T}_{\mathrm{H}} 1$ cells was decreased in macrophage-depleted NOD mice, indicating that down-regulation of the $\mathrm{T}_{\mathrm{H}} 1$ immune response and upregulation of the $\mathrm{T}_{\mathrm{H}} 2$ immune response may be factors in the loss of the ability of $\mathrm{T}$ cells in a macrophagedepleted environment to kill $\beta$ cells. ${ }^{69} \mathrm{~T}$ cell proliferation to islet antigens or GAD was significantly decreased when splenocytes from macrophagedepleted NOD mice were used as APCs, suggesting

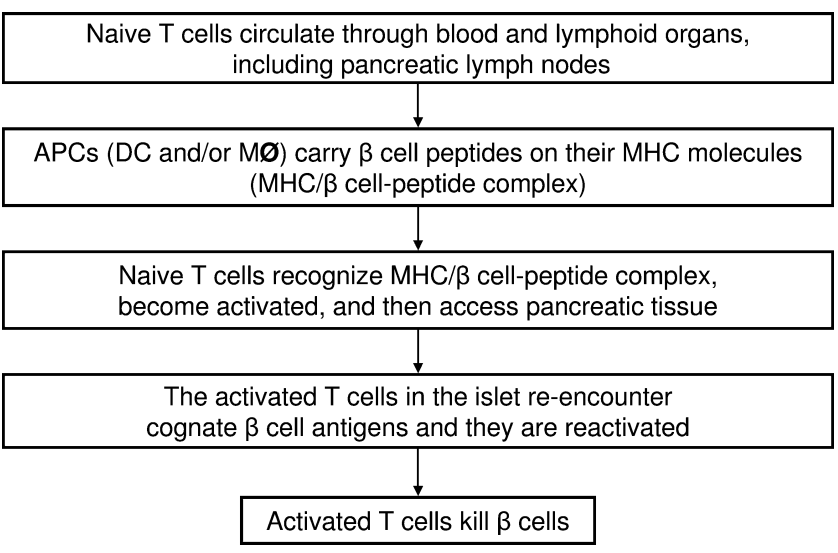

FIGURE 2. Activation of $\beta$ cell-autoreactive T cells by $\beta$ cell autoantigens and APCs in autoimmune type 1 diabetes. Naive $\beta$ cell-autoreactive T cells may circulate through the blood and lymphoid organs. $\beta$ Cell autoantigens are processed and presented by APCs (dendritic cells [DC], macrophages, and B cells) in the pancreatic islets. Mature APCs, which present $\beta$ cell autoantigen peptides in conjunction with $\mathrm{MHC}$ molecules, migrate to the pancreatic lymph nodes. Naive $\beta$ cell-autoreactive $\mathrm{T}$ cells in the circulation recognize the $\mathrm{MHC} / \beta$ cell autoantigen peptide complex on APCs and become activated. These activated $\beta$ cell-reactive $T$ cells access the pancreatic islets and reencounter cognate $\beta$ cell antigens and become reactivated. The activated $\beta$ cell-reactive T cells can then kill $\beta$ cells.

American Journal of Therapeutics (2005) 12(6) 


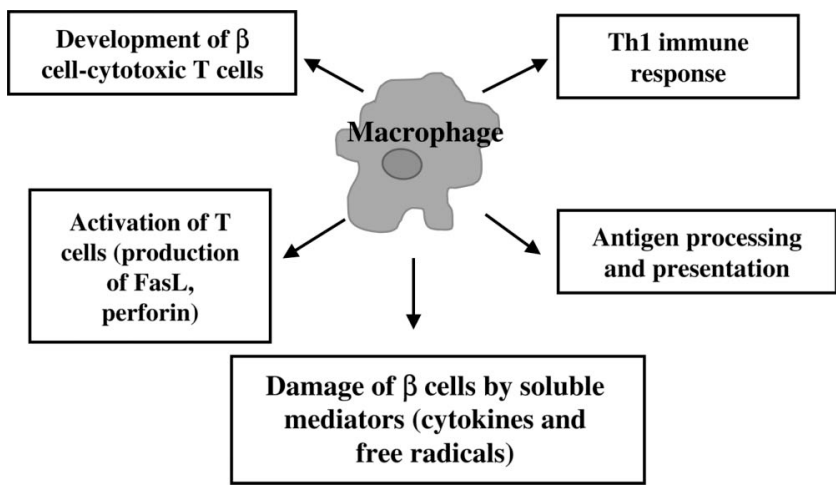

FIGURE 3. Role of macrophages in the development of autoimmune type 1 diabetes. Macrophages are involved in $\beta$ cell antigen processing and presentation and the induction of the $T_{H} 1$ immune response, contributing to the creation of microenvironment for the development and activation of $\beta$ cell cytotoxic T cells. In addition, macrophages produce soluble mediators that are toxic to $\beta$ cells. This results in the destruction of $\beta$ cells and subsequent development of autoimmune diabetes.

that depletion of macrophages results in the reduction of APC function and subsequently down-regulation of antigen-specific $\mathrm{CD}^{+} \mathrm{T}$ cell activation (Fig. 3 ).

Splenic T cells from macrophage-depleted NOD mice showed a significant decrease in the expression of FasL and perforin as compared with macrophage-containing NOD mice. ${ }^{69}$ This result suggests that macrophages are required for the activation of cytotoxic $T$ cells that can destroy pancreatic $\beta$ cells. Taken together, we suggest that IL-12 secreted by macrophages may activate $\mathrm{T}_{\mathrm{H}} 1-$ type $\mathrm{CD} 4^{+}$T cells and subsequently the IL- 2 and IFN- $\gamma$ produced by these activated $\mathrm{CD} 4^{+} \mathrm{T}$ cells may assist in maximizing the activation of $\mathrm{CD}^{+} \mathrm{T}$ cells. Downregulation of islet cell-specific $\mathrm{T}$ cell activation may be another factor contributing to the impairment of the capability of $\mathrm{T}$ cells to kill $\beta$ cells in macrophagedepleted NOD mice.

Macrophages can also damage $\beta$ cells by production of soluble mediators such as oxygen free radicals and other cytokines including IL- $1 \beta$, TNF- $\alpha$, and IFN- $\gamma^{70-73}$ (Fig. 3). The toxic effect produced by activated macrophages on $\beta$ cells is thought to be mediated by the superoxide anion and hydrogen peroxide. The expression of IL- $1 \beta$, TNF- $\alpha$, and IFN- $\gamma$ is detected during early insulitis in NOD mice and BB rats. ${ }^{74,75}$ It has been reported that IL-1 is selectively cytotoxic to pancreatic $\beta$ cells in vitro, ${ }^{76}$ and IL-1 receptors are present on $\beta$ cells. ${ }^{77}$ IL-1 and TNF- $\alpha$ inhibit insulin secretion from isolated islets. ${ }^{78,79}$ The destruction of $\beta$ cells induced by IL-1 is potentiated by TNF- $\alpha$. In vitro studies reveal that the cytotoxic effect of IL-6, TNF- $\alpha$, lymphotoxin, and IFN- $\gamma$ on the islets is cumulative. These mediators, acting alone or synergistically, destroy islets. Thus, treatment with IL-1 receptor antagonist, soluble IL-1 receptor, anti-IL-6 antibody, anti-TNF- $\alpha$ antibody, or anti-IFN- $\gamma$ antibody decreases the incidence of diabetes. ${ }^{80}$

Activated macrophages produce reactive oxygen species including oxygen radicals, hydroxyl radicals, and NO species (Fig. 3). Studies suggest that IL-1 $\beta$ - and TNF- $\alpha$-stimulated endogenous iNOS activity induces NO production in $\beta$ cells, which contributes to $\beta$ cell injury. ${ }^{81}$ The generation of NO in response to cytokines in $\beta$ cells ${ }^{82}$ and the generation of peroxynitrite was detected in $\beta$ cells of NOD mice. ${ }^{83}$ The $\beta$ cells are very sensitive to free radicals because $\beta$ cells exhibit very low free radical scavenging activity. ${ }^{84,85}$ Thus, overexpression of cytosolic superoxide dismutase (Cu/Zn-SOD) in $\beta$ cells prevents diabetes. ${ }^{86,87}$ In addition, SOD mimetics protect from diabetes induced by the diabetogenic T cell clone, BDC2.5, in NOD.scid mice. ${ }^{88}$ Reactive oxygen species can damage $\beta$ cells by causing DNA strand breaks, which induce the DNA repair enzyme poly(ADP) ribose polymerase (PARP). PARP uses and depletes nicotinamide adenosine dinucleotide (NAD), leading to necrosis of $\beta$ cells. In line with this, PARP-deficient mice are resistant to diabetes induced by a low dose of streptozotocin. ${ }^{89}$

\section{T CELLS}

It is known that both MHC class II-restricted CD4 ${ }^{+}$ $\mathrm{T}$ cells and $\mathrm{MHC}$ class I-restricted $\mathrm{CD} 8^{+} \mathrm{T}$ cells play a critical role in the pathogenesis of type 1 diabetes in NOD mice. Athymic NOD and NOD.scid mice do not develop insulitis or diabetes. ${ }^{90,91}$ In addition, treatment of NOD mice with anti-CD3 antibodies inhibits the development of diabetes. ${ }^{92}$ However, the precise role of $\mathrm{CD}^{+}$and $\mathrm{CD}^{+} \mathrm{T}$ cells in the pathogenesis of autoimmune type 1 diabetes is not clearly understood.

Both $\mathrm{CD}^{+}$and $\mathrm{CD} 8^{+} \mathrm{T}$ cells are required to transfer diabetes, and $\mathrm{CD} 4^{+} \mathrm{T}$ cells transfer insulitis, but not diabetes to NOD.scid mice. ${ }^{91} \mathrm{CD} 4^{+} \mathrm{T}$ cells are required for the recruitment of $\beta$ cell-cytotoxic $C D 8^{+} \mathrm{T}$ cells into the islets, ${ }^{93}$ but some $\mathrm{CD} 8^{+} \mathrm{T}$ cell clones from diabetic NOD mice can transfer diabetes without the help of $\mathrm{CD}^{+}{ }^{+}$T cells. $^{94,95}$ However, other results showed that some $\mathrm{CD}^{+} \mathrm{T}$ cell clones can induce diabetes in the absence of $\mathrm{CD}^{+}{ }^{\mathrm{T}}$ cells, ${ }^{96}$ and splenocytes from diabetic donors can transfer disease into recipients lacking MHC class I expression on their islets, ${ }^{97}$ suggesting that $\mathrm{CD} 4^{+} \mathrm{T}$ cells alone have the ability to induce diabetes.

We have cloned many $\mathrm{CD}^{+}$and $\mathrm{CD}^{+}$islet-reactive $\mathrm{T}$ cells from lymphocytes infiltrating the pancreatic islets of NOD mice ${ }^{98}$ (Table 1). Islet-specific CD8 ${ }^{+} \mathrm{T}$ cell 
Table 1. $\mathrm{CD} 4^{+}$and $\mathrm{CD} 8^{+} \mathrm{T}$ cell clones and their reactivity characteristics.

\begin{tabular}{|c|c|c|c|}
\hline Clones* & Phenotype & $\begin{array}{l}\text { Destruction } \\
\text { of } \beta \text { cells }{ }^{\dagger}\end{array}$ & $\begin{array}{c}\text { Cytotoxicity } \\
\text { to NOD islets } \\
\left({ }^{51} \mathrm{Cr} \text {-release assay }\right. \\
\mathrm{T} / \mathrm{E}=1 / 20, \%)^{\ddagger}\end{array}$ \\
\hline NY1.1 & CD4 & + & 6.3 \\
\hline NY3.1 & CD4 & + & 5.7 \\
\hline NY3.2 & CD4 & - & 1.2 \\
\hline NY4.1 & CD4 & + & 5.9 \\
\hline NY4. & CD4 & - & 1.1 \\
\hline NY2.3 & CD8 & +++ & 26.3 \\
\hline NY5.2 & CD8 & ++ & 19.5 \\
\hline NY6.3 & CD8 & ++ & 20.6 \\
\hline NY8.3 & CD8 & +++ & 28.7 \\
\hline NY9.3 & CD8 & ++ & 22.1 \\
\hline
\end{tabular}

${ }^{*} \mathrm{CD}^{+}$and $\mathrm{CD}^{+} \mathrm{T}$ cells were cloned from the islet infiltrates of acutely diabetic female NOD mice.

${ }^{\dagger}$ Destruction of $\beta$ cells was evaluated by morphological examination using light and electron microscopy.

${ }^{\ddagger}$ Cytotoxicity to islet cells was evaluated by morphological examination using phase-contrast microscopy and ${ }^{51} \mathrm{Cr}$-release cytotoxicity assay.

$\mathrm{T} / \mathrm{E}$, target/effector.

clones selectively destroyed $\beta$ cells in vitro (Figs. 4 and 5), whereas $\mathrm{CD}^{+} \mathrm{T}$ cell clones did not destroy $\beta$ cells but attached closely to them ${ }^{84}$ (Fig. 4). Further studies using cloned $\mathrm{CD}^{+}$and $\mathrm{CD} 8^{+} \mathrm{T}$ cells revealed that MHC class I-restricted cytotoxic $\mathrm{CD}^{+} \mathrm{T}$ lymphocytes play an important role as final effectors in $\beta$ cell destruction in vivo and that $\mathrm{CD}^{+} \mathrm{T}$ cells are required for the activation of $\mathrm{CD} 8^{+} \mathrm{T}$ cells and their recruitment into the pancreatic islets. ${ }^{93,98}$ Among the $\mathrm{CD}^{+}$and $\mathrm{CD}^{+}$T cell clones produced, NY8.3 (CD8 ${ }^{+} \mathrm{T}$ cell clone) and NY4.1 (CD4 ${ }^{+}$T cell clone) were used to establish $T$ cell receptor transgenic mice. TCR- $\beta$ transgenic NOD mice with TCR- $\beta$ rearrangements of NY8.3 showed a 10-fold increase in frequency of precursors of $\beta$ cell- specific cytotoxic $\mathrm{T}$ lymphocytes and an accelerated onset, but not an increased incidence, of diabetes. ${ }^{99}$ TCR- $\alpha \beta$ transgenic mice, with both $\alpha$ - and $\beta$-TCR rearrangements of NY8.3, showed a 400-fold increase in the peripheral frequency of $\beta$ cell-specific cytotoxic lymphocytes and a dramatically accelerated onset of diabetes without an increase in disease incidence. ${ }^{100}$ TCR- $\alpha \beta$ transgenic mice with both $\alpha$ - and $\beta$-TCR rearrangements of the NY4.1 clone $^{98}$ also showed an accelerated onset of diabetes as a result of a more rapid progression of islet inflammation. ${ }^{100}$ However, mice with only the TCR $-\beta$ rearrangement of NY4.1 became diabetic later than the mice with the TCR- $\alpha$ and $-\beta$ rearrangement of NY4.1, indicating that the accelerated onset of diabetes in these mice required the coexpression of both the TCR- $\alpha$ and $-\beta$ transgenes.

Cytokines produced by T cells also play an important role in the pathogenesis of autoimmune type 1 diabetes (Figs. 1 and 6). Many different approaches have been tried to study the role of cytokines in the pathology of type 1 diabetes, including systemic administration of cytokines, neutralization of cytokines, and knockout of cytokine genes. ${ }^{101}$ In general, $\mathrm{T}_{\mathrm{H}} 1$ cytokines (IL-2, IFN- $\gamma$, TNF- $\beta$ ) cause the development of the disease, whereas $\mathrm{T}_{\mathrm{H}} 2$ or Th3 cytokines (IL-4, IL-10, TGF- $\beta$ ) prevent the disease. However, the role of cytokines in the pathogenesis of autoimmune type 1 diabetes is complex. Treatment of NOD mice with anti-IFN- $\gamma$ antibody prevented the development of diabetes, ${ }^{102}$ and transgenic expression of IFN- $\gamma$ resulted in the development of diabetes in diabetes-resistant mice. ${ }^{103}$ However, the genetic absence of IFN- $\gamma$ in NOD mice results in a delay in the development of diabetes but does not prevent its development. ${ }^{104}$ Systemic administration of IL- $4{ }^{105}$ or IL-10 ${ }^{106}$ prevented type 1 diabetes in NOD mice, and the transgenic expression of IL- 4 in $\beta$ cells also prevented the disease. ${ }^{107}$ However, local expression of IL-10 in the islets accelerated the development of diabetes in NOD mice, and IL-4 knockout NOD mice
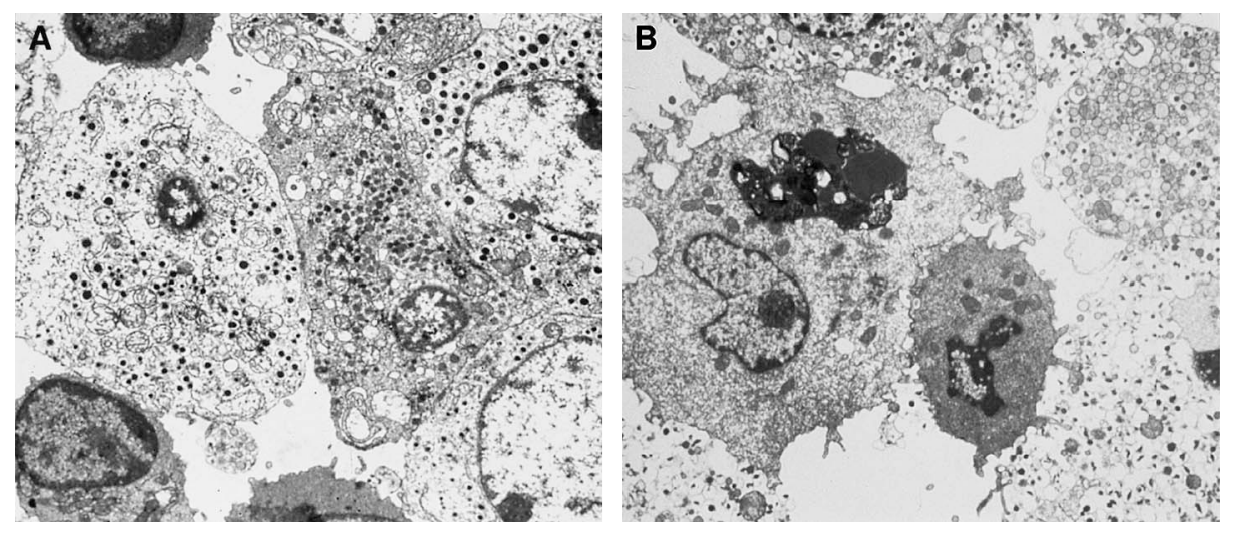

FIGURE 4. Distinct difference in interaction with $\beta$ cells between $\mathrm{CD}^{+}$ and $\mathrm{CD} 8^{+} \mathrm{T}$ cell clones. Islet-derived $\mathrm{T}$ cell clones NY4.1 $\left(\mathrm{CD}^{+}\right)(\mathrm{A})$ and NY2.3 $\left(\mathrm{CD}^{+}\right)$(B) were incubated with islets from silica-treated NOD mice. After 2.5 hours, tissues were examined by electron microscopy. A: $\mathrm{CD}^{+}{ }^{+} \mathrm{T}$ cells (NY4.1) attached closely to $\beta$ cells but did not cause cell lysis. B: $\mathrm{CD}^{+} \mathrm{T}$ cells (NY2.3) attached closely to $\beta$ cells and extended pseudopods into them, causing cell damage (loss of plasma membrane and electron-dense cytoplasm). 
did not show accelerated disease onset. ${ }^{108}$ Therefore, the interactions of the many different cytokines in the immune system are complex and the development of diabetes may depend on which way the finely tuned immune balance of immunoregulatory T cells is tipped (Figs. 1 and 6).

Effector T cells destroy $\beta$ cells through direct contact with surface ligands of apoptosis-inducing receptors, such as FasL and membrane-bound TNF- $\alpha$, or through the secretion of perforin molecules, which facilitate the passage of protease granzymes (Figs. 1 and 6). Granzymes activate nucleases in the cells and kill them. In addition, proinflammatory cytokines produced from $\mathrm{T}$ cells contribute to the apoptosis of $\beta$ cells. Systemic Fas-deficient NOD mice did not develop insulitis or diabetes, ${ }^{109}$ and the expression of Fas increases during
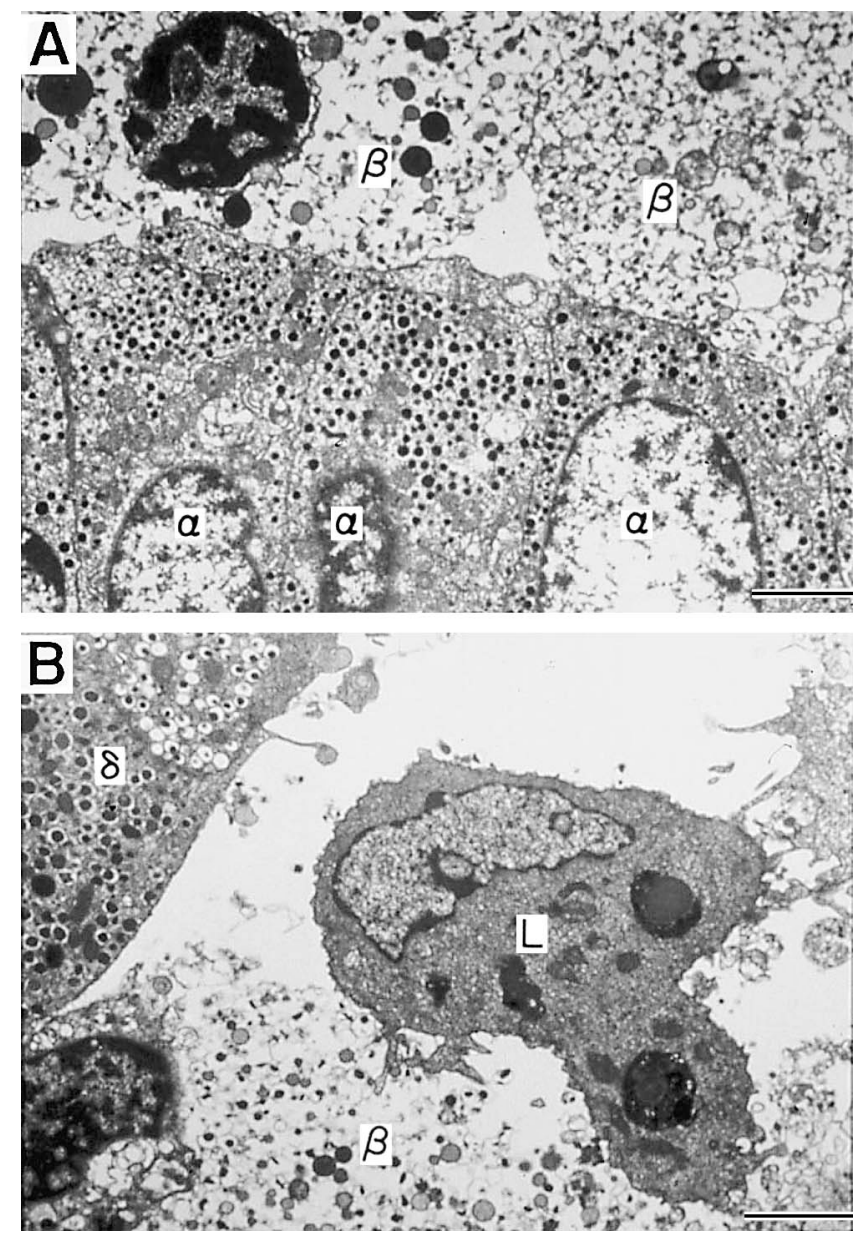

FIGURE 5. Selective destruction of $\beta$ cells by NY2.3 $\left(\mathrm{CD}^{+}\right) \mathrm{T}$ cells. NY2.3T cells were incubated with islets from silica-treated NOD mice. After 2.5 hours, tissues were examined under the electron microscope. $\beta$ cells $(\beta)$ were extensively damaged, whereas $\alpha$ cells $(\alpha)(A)$ and $\delta$ cells $(\delta)$ (B) were spared. L, CD8 ${ }^{+}$cytotoxic T lymphocyte. Horizontal bar $=0.1 \mu \mathrm{m}$.

American Journal of Therapeutics (2005) 12(6) the development of diabetes, suggesting that Fas plays an important role in $\beta$ cell destruction. However, a recent study reported that $\beta$ cell-specific Fas-deficient mice, in which $\mathrm{CD} 4^{+} \mathrm{T}$ cells with a transgenic TCR specific for influenza hemagglutinin (HA) cause diabetes in mice that express HA under control of the rat insulin promoter, developed autoimmune diabetes with slightly accelerated kinetics, indicating that Fas-dependent apoptosis of $\beta$ cells is a dispensable mode of $\beta$ cell death in autoimmune type 1 diabetes. ${ }^{110}$ TNF receptor 1 -deficient NOD mice failed to develop diabetes, ${ }^{111}$ and NOD mice lacking perforin expression developed insulitis but not diabetes, ${ }^{112}$ suggesting that the TNF and perforin pathway appears to play an important role for $\beta$ cell killing.

\section{CONCLUSION}

The cause of autoimmune type 1 diabetes is multifactorial, and both genetic and environmental factors are involved in the initiation and progression of $\beta$ cell destruction. Thus, the elucidation of pathogenic mechanisms involved in the etiology of the disease is difficult. Based on experimental results from studies using NOD mice and BB rats over the past 3 decades, we have reviewed the possible pathogenic mechanisms involved in the autoimmune destruction of pancreatic $\beta$ cells in type 1 diabetes and summarized them in the model shown in Figure 1. This model shows the possible interactions between $\beta$ cell autoantigens and immunocytes such as macrophages, dendritic cells, T cells, and their secretory products in connection with MHC class I and II molecules, based on our research and that of others primarily using animal models of type 1 diabetes. This model may not encompass all aspects of the pathogenic mechanisms involved in autoimmune diabetes in humans; nevertheless, it may provide helpful information with respect to the synergistic destruction of pancreatic $\beta$ cells by immunocytes and their cytokines and a basis for the formation of new hypotheses for further investigation.

\section{ACKNOWLEDGMENTS}

The authors gratefully acknowledge the editorial assistance of Dr. Ann Kyle. This work was supported by grant MA9584 from the Canadian Institutes of Health Research and the American Diabetes Association to J.W.Y. 


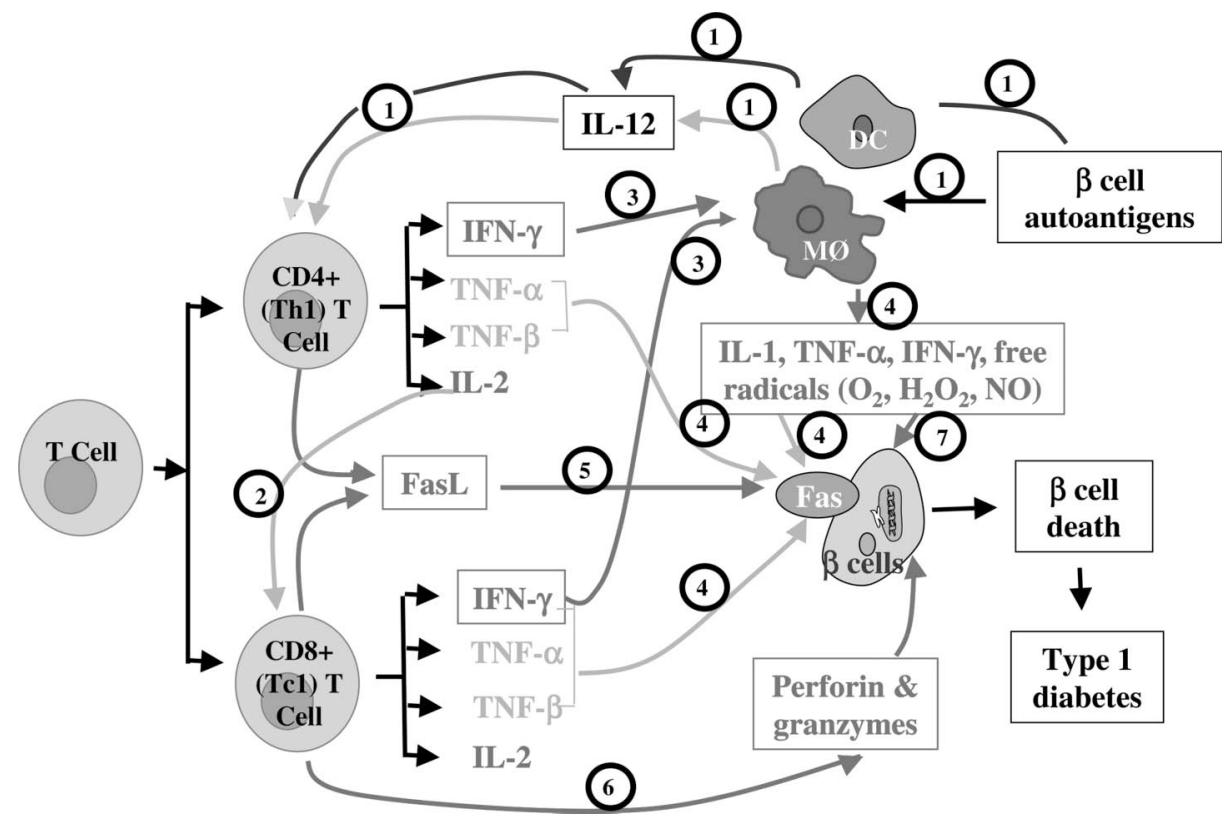

FIGURE 6. Schematic representation of the collaboration between macrophages and $\mathrm{T}$ cells in the destruction of pancreatic $\beta$ cells. $\beta$ Cell autoantigens may be released from the $\beta$ cells during spontaneous turnover of $\beta$ cells. The antigens are then processed by dendritic cells (DC) and/or macrophages (MØ) and presented to helper $\mathrm{T}$ cells $\left(\mathrm{CD} 4^{+} \mathrm{T}_{\mathrm{H}} 1\right.$ cell) in conjunction with $\mathrm{MHC}$ class II molecules. The activated macrophages secrete IL-12, which activates $C D 4^{+} T_{H} 1$-type $T$ cells (1). The $\mathrm{CD}^{+} \mathrm{T}$ cells secrete cytokines such as IFN- $\gamma$, TNF- $\alpha$, TNF- $\beta$, and IL-2. While this process is taking place, $\beta$ cell-specific precytotoxic $T$ cells (CD8 ${ }^{+}$Tc1 T cell) may be recruited into the islets. These precytotoxic $T$ cells may be activated by IL-2 and other cytokines released by $C D 4^{+} \mathrm{T}_{\mathrm{H}} 1$ cells to differentiate into $\mathrm{CD} 8^{+}$effector T cells ( 2 ). IFN$\gamma$ released by $C D 4^{+} T_{H} 1$ cells and cytotoxic $C D 8^{+} T$ cells may cause macrophages to become cytotoxic (3). These cytotoxic macrophages release substantial amounts of $\beta$ cell-cytotoxic cytokines (including IL-1 $\beta$, TNF- $\alpha$, and IFN- $\gamma$ ). Cytokines released from macrophages and T cells may induce the expression of Fas on pancreatic $\beta$ cells. $\beta$ Cells are destroyed by Fasmediated apoptosis $(4,5)$ and/or granzymes and perforin (cytolysin), which are toxic to $\beta$ cells (6). Oxygen free radicals (nitric oxide, $\mathrm{H}_{2} \mathrm{O}_{2}$ ) secreted from activated macrophages can also kill $\beta$ cells (7).

\section{REFERENCES}

1. Lernmark A, Falorni A. Immune phenomena and events in the islets in insulin-dependent diabetes mellitus. In: Pickup JC, Williams G, eds. Textbook of Diabetes, 2nd ed. Oxford: Blackwell Science; 1997:15.1-15.23.

2. Atkinson MA, McLaren NK. The pathogenesis of insulin-dependent diabetes mellitus. $N$ Engl J Med. 1994;31:1428-1436.

3. Schranz DB, Lernmark A. Immunology in diabetes: an update. Diabetes Metab Rev. 1998;14:3-29.

4. She JX, Marron MP. Genetic susceptibility factors in type 1 diabetes: linkage, disequilibrium and functional analyses. Curr Opin Immunol. 1998;10:682-689.

5. Onengut-Gumuscu S, Concannon P. Mapping genes for autoimmunity in humans: type 1 diabetes as a model. Immunol Rev. 2002;190:182-194.

6. Barnett AH, Eff C, Leslie RD, et al. Diabetes in identical twins. A study of 200 pairs. Diabetologia. 1981;20: 87-93.

7. Gepts W, Lecompte PM. The pancreatic islets in diabetes. Am J Med. 1981;70:105-115.

8. Hanninen A, Jalkanen S, Salmi M, et al. Macrophages, $T$ cell receptor usage, and endothelial cell activation in the pancreas at the onset of insulin-dependent diabetes mellitus. J Clin Invest. 1992;90:1901-1910.

9. Itoh N, Hanafusa T, Miyazaki A, et al. Mononuclear cell infiltration and its relation to the expression of major histocompatibility complex antigens and adhesion molecules in pancreas biopsy specimens from newly diagnosed insulin-dependent diabetes mellitus patients. J Clin Invest. 1993;92:2313-2322.

10. Baekkeskov S, Landin M, Kristensen JK, et al. Antibodies to a $64,000 \mathrm{Mr}$ human islet cell antigen precede the clinical onset of insulin-dependent diabetes. J Clin Invest. 1987;79:926-934.

11. Hawkes CJ, Schloot NC, Marks J, et al. T-cell lines reactive to an immunodominant epitope of the tyrosine phosphatase-like autoantigen IA-2 in type 1 diabetes. Diabetes. 2000;49:356-366.

12. Dromey JA, Weenink SM, Peters GH, et al. Mapping of epitopes for autoantibodies to the type 1 diabetes autoantigen IA-2 by peptide phage display and molecular modeling: overlap of antibody and T cell determinants. J Immunol. 2004;172:4084-4090.

13. Neophytou PI, Roep BO, Arden SD, et al. T-cell epitope analysis using subtracted expression libraries (TEASEL): application to a 38-kDA autoantigen recognized by T cells from an insulin-dependent diabetic patient. Proc Natl Acad Sci U S A. 1996;93:2014-2018.

14. Durinovic-Bello I, Steinle A, Ziegler AG, et al. HLA-DQrestricted, islet-specific T-cell clones of a type I diabetic patient. T-cell receptor sequence similarities to insulitisinducing T-cells of nonobese diabetic mice. Diabetes. 1994;43:1318-1325.

15. Tisch R, McDevitt H. Insulin-dependent diabetes mellitus. Cell. 1996;85:291-297.

American Journal of Therapeutics (2005) 12(6) 
16. Delovitch TL, Singh B. The nonobese diabetic mouse as a model of autoimmune diabetes: immune dysregulation gets the NOD. Immunity. 1997;7:727-738.

17. Yoon JW, Jun HS. Insulin-dependent diabetes mellitus. In: Roitt IM, Delves PJ, eds. Encyclopedia of Immunology, 2nd ed. London: Academic Press; 1998:1390-1398.

18. Rossini AA, Greiner DL, Friedman HP, et al. Immunopathogenesis of diabetes mellitus. Diabetes Rev. 1993;1: 43-75.

19. Bach JF. Insulin-dependent diabetes mellitus as a $\beta$ cell targeted disease of immunoregulation. J Autoimmun. 1995; 8:439-463.

20. Palmer JP, Asplin CM, Clemons $P$, et al. Insulin antibodies in insulin-dependent diabetics before insulin treatment. Science. 1983;222:1337-1339.

21. Baekkeskov S, Aanstoot HJ, Christgau S, et al. Identification of the $64 \mathrm{~K}$ autoantigen in insulin-dependent diabetes as the GABA-synthesizing enzyme glutamic acid decarboxylase. Nature. 1990;347:151-156.

22. Bonifacio E, Lampasona V, Genovese S, et al. Identification of protein tyrosine phosphatase-like IA2 (islet cell antigen 512) as the insulin-dependent diabetes-related $37 / 40 \mathrm{~K}$ autoantigen and a target of islet-cell antibodies. J Immunol. 1995;155:5419-5426.

23. Lu J, Li Q, Xie $\mathrm{H}$, et al. Identification of a second transmembrane protein tyrosine phosphatase, IA-2beta, as an autoantigen in insulin-dependent diabetes mellitus: precursor of the 37-kDa tryptic fragment. Proc Natl Acad Sci U S A. 1996;93:2307-2311.

24. Castano L, Russo E, Zhou L, et al. Identification and cloning of a granule autoantigen (carboxypeptidase-H) associated with type I diabetes. J Clin Endocrinol Metab. 1991;73:1197-1201.

25. Pietropaolo M, Castano L, Babu S, et al. Islet cell autoantigen $69 \mathrm{kD}$ (ICA69). Molecular cloning and characterization of a novel diabetes-associated autoantigen. J Clin Invest. 1993;92:359-371.

26. Nayak RC, Omar MA, Rabizadeh A, et al. "Cytoplasmic" islet cell antibodies. Evidence that the target antigen is a sialoglycoconjugate. Diabetes. 1985;34:617619.

27. Arden SD, Roep BO, Neophytou PI, et al. Imogen 38: a novel $38-\mathrm{kD}$ islet mitochondrial autoantigen recognized by $\mathrm{T}$ cells from a newly diagnosed type 1 diabetic patient. J Clin Invest. 1996;97:551-561.

28. Kasimiotis H, Myers MA, Argentaro A, et al. Sexdetermining region Y-related protein SOX13 is a diabetes autoantigen expressed in pancreatic islets. Diabetes. 2000; 49:555-561.

29. Verge CF, Gianani R, Kawasaki E, et al. Prediction of type I diabetes in first-degree relatives using a combination of insulin, GAD, and ICA512bdc/IA-2 autoantibodies. Diabetes. 1996;45:926-933.

30. Sanjeevi CB, Falorni A, Robertson J, et al. Glutamic acid decarboxylase in IDDM. Diabetes Nutr Metab. 1996;9: 167-182.

31. Velloso LA, Kampe O, Hallberg A, et al. Demonstration of GAD-65 as the main immunogenic isoform of glutamate decarboxylase in type 1 diabetes and determination of autoantibodies using a radioligand produced by eukaryotic expression. J Clin Invest. 1993;91:2084-2090.

32. Richter W, Shi Y, Baekkeskov S. Autoreactive epitopes defined by diabetes-associated human monoclonal antibodies are localized in the middle and C-terminal domains of the smaller form of glutamate decarboxylase. Proc Natl Acad Sci U S A. 1993;90:2832-2836.

33. Tisch R, Yang XD, Singer SM, et al. Immune response to glutamic acid decarboxylase correlates with insulitis in non-obese diabetic mice. Nature. 1993;366:72-75.

34. DeAizpurua HJ, French MB, Chosich N, et al. Natural history of humoral immunity to glutamic acid decarboxylase in non-obese diabetic (NOD) mice. J Autoimmun. 1994;7:643-653.

35. Kaufman DL, Clare-Salzler M, Tian J, et al. Spontaneous loss of T-cell tolerance to glutamic acid decarboxylase in murine insulin-dependent diabetes. Nature. 1993;366: 69-72.

36. Zekzer D, Wong FS, Ayalon O, et al. GAD-reactive CD4 ${ }^{+}$ Th1 cells induce diabetes in NOD/SCID mice. J Clin Invest. 1998;101:68-73.

37. Quim A, MacInerney MF, Sercarz EE. MHC class Irestricted determinants on the glutamic acid decarboxylase 65 molecular induce spontaneous CTL activity. J Immunol. 2001;167:1748-1757.

38. Atkinson MA, Kaufman DL, Campbell L, et al. Response of peripheral blood mononuclear cells to glutamate decarboxylase in insulin-dependent diabetes. Lancet. 1992;339:458-459.

39. Endl J, Otto H, Jung G, et al. Identification of naturally processed $T$ cell epitopes from glutamic acid decarboxylase presented in the context of HLA-DR alleles by T lymphocytes of recent onset IDDM patients. $J$ Clin Invest. 1997;99:2405-2415.

40. Honeyman MC, Cram DS, Harrison LC. Glutamic acid decarboxylase 67-reactive T cells: a maker of insulindependent diabetes. J Exp Med. 1993;177:535-540.

41. Panina-Bordignon P, Lang R, van Endert PM, et al. Cytotoxic T cells specific for glutamic acid decarboxylase in autoimmune diabetes. J Exp Med. 1995;181:19231927.

42. Schloot NC, Daniel D, Norbury-Glaser $M$, et al. Peripheral $\mathrm{T}$ cell clones from NOD mice specific for GAD65 peptides: lack of islet responsiveness or diabetogenicity. J Autoimmun. 1996;9:357-363.

43. Chen SL, Whiteley PJ, Freed DC, et al. Responses of NOD congenic mice to glutamic acid decarboxylasederived peptide. J Autoimmun. 1994;7:635-641.

44. Atkinson MA, Bowman MA, Campbell L, et al. Cellular immunity to an epitope common to glutamate decarboxylase and Coxsackie virus in insulin-dependent diabetes. J Clin Invest. 1994;94:2125-2129.

45. Richter W, Mertens T, Schoel B, et al. Muir Sequence homology of the diabetes-associated autoantigen glutamate decarboxylase with Coxsackie B4-2C protein and heat shock protein 60 mediates no molecular mimicry of autoantibodies. J Exp Med. 1994;180:721-726. 
46. Bridgett $M$, Cetkovic-Cvrlje $M, O^{\prime}$ Rourke $R$, et al. Differential protection in two transgenic lines of NOD/Lt mice hyperexpressing the autoantigen GAD65 in pancreatic beta-cells. Diabetes. 1998;47:1848-1856.

47. Geng L, Solimena M, Flavell RA, et al. Widespread expression of an autoantigen-GAD65 transgene does not tolerize non-obese diabetic mice and can exacerbate disease. Proc Natl Acad Sci U S A. 1998;95:1005510060.

48. Yoon JW, Yoon CS, Lim HW, et al. Control of autoimmune diabetes in NOD mice by GAD expression or suppression in beta cells. Science. 1999;284:1183-1187.

49. Yoon JW, Sherwin RS, Kwon H, et al. Has GAD a central role in type 1 diabetes? J Autoimmun. 2000;15:273-278.

50. Jaeckel E, Klein L, Martin-Orozco N, et al. Normal incidence of diabetes in NOD mice tolerant to glutamic acid decarboxylase. J Exp Med. 2003;197:1635-1644.

51. Kash SF, Condie BG, Baekkeskov S. Glutamate decarboxylase and GABA in pancreatic islets: lessons from knock-out mice. Horm Metab Res. 1999;31:340-344.

52. Greenbaum CJ, Palmer JP, Kuglin B, et al. Insulin autoantibodies measured by radioimmunoassay methodology are more related to insulin-dependent diabetes mellitus than those measured by enzyme-linked immunosorbent assay: results of the Fourth International Workshop on the Standardization of Insulin Autoantibody Measurement. J Clin Endocrinol Metab. 1992;74:1040-1044.

53. Ziegler AG, Hummel M, Schenker M, et al. Autoantibody appearance and risk for development of childhood diabetes in offspring of parents with type 1 diabetes: the 2-year analysis of the German BABYDIAB Study. Diabetes. 1999;48:460-468.

54. Yu L, Robles DT, Abiru N, et al. Early expression of antiinsulin autoantibodies of humans and the NOD mouse: evidence for early determination of subsequent diabetes. Proc Natl Acad Sci U S A. 2000;97:1701-1706.

55. Daniel D, Gill RG, Schloot N, et al. Epitope specificity, cytokine production profile and diabetogenic activity of insulin-specific T cell clones isolated from NOD mice. Eur J Immunol. 1995;25:1056-1062.

56. French MB, Allison J, Cram DS, et al. Transgenic expression of mouse proinsulin II prevents diabetes in nonobese diabetic mice. Diabetes. 1997;46:34-39.

57. Christie MR, Vohra G, Champagne P, et al. Distinct antibody specificities to a $64-\mathrm{kD}$ islet cell antigen in type 1 diabetes as revealed by trypsin treatment. J Exp Med. 1990;172:789-794.

58. Lan MS, Lu J, Goto Y, et al. Molecular cloning and identification of a receptor-type protein tyrosine phosphatase, IA-2, from human insulinoma. DNA Cell Biol. 1994;13:505-514.

59. Wasmeier C, Hutton JC. Molecular cloning of phogrin, a protein-tyrosine phosphatase homologue localized to insulin secretory granule membranes. J Biol Chem. 1996; 271:18161-18170.

60. Gorus FK, Goubert P, Semakula C, et al. IA-2-autoantibodies complement GAD65-autoantibodies in newonset IDDM patients and help predict impending diabetes in their siblings. The Belgian Diabetes Registry. Diabetologia. 1997;40:95-99.

61. Kolb H, Kantwerk G, Treichel U, et al. Prospective analysis of islet lesions in BB rats. Diabetologia. 1986; 29(suppl 1):A559.

62. Voorbij HA, Jeucken PH, Kabel PJ, et al. Dendritic cells and scavenger macrophages in pancreatic islets of prediabetic BB rats. Diabetes. 1989;38:1623-1629.

63. Jansen A, Homo-Delarche F, Hooijkaas H, et al. Immunohistochemical characterization of monocytes-macrophages and dendritic cells involved in the initiation of the insulitis and beta-cell destruction in NOD mice. Diabetes. 1994;43:667-675.

64. Amano K, Yoon JW. Studies on autoimmunity for initiation of beta-cell destruction. V. Decrease of macrophage-dependent $\mathrm{T}$ lymphocytes and natural killer cytotoxicity in silica-treated BB rats. Diabetes. 1990;39:590-596.

65. Serreze DV, Fleming SA, Chapman HD, et al. B lymphocytes are critical antigen-presenting cells for the initiation of $\mathrm{T}$ cell-mediated autoimmune diabetes in nonobese diabetic mice. J Immunol. 1998;161:3912-3918.

66. Lee KU, Amano K, Yoon JW. Evidence for initial involvement of macrophage in development of insulitis in NOD mice. Diabetes. 1988;37:989-991.

67. Oschilewski U, Kiesel U, Kolb H. Administration of silica prevents diabetes in BB-rats. Diabetes. 1985;34:197199.

68. Lee KU, Kim MK, Amano K, et al. Preferential infiltration of macrophages during early stages of insulitis in diabetes-prone BB rats. Diabetes. 1988;37:1053-1058.

69. Jun HS, Yoon CS, Zbytnuik L, et al. The role of macrophages in T cell-mediated autoimmune diabetes in nonobese diabetic mice. J Exp Med. 1999;189:347-358.

70. Pankewycz OG, Guan JX, Benedict JF. Cytokines as mediators of autoimmune diabetes and diabetic complications. Endocr Rev. 1995;16:164-176.

71. Mandrup-Poulsen T, Bendtzen K, Dinarello CA, et al. Human tumor necrosis factor potentiates human interleukin 1-mediated rat pancreatic beta-cell cytotoxicity. J Immunol. 1987;139:4077-4082.

72. Appels B, Burkart V, Kantwerk-Funke G, et al. Spontaneous cytotoxicity of macrophages against pancreatic islet cells. J Immunol. 1989;142:3803-3808.

73. Pukel C, Baquerizo H, Rabinovitch A. Destruction of rat islet cell monolayers by cytokines. Synergistic interactions of interferon-gamma, tumor necrosis factor, lymphotoxin, and interleukin 1. Diabetes. 1988;37:133-136.

74. Jiang Z, Woda BA. Cytokine gene expression in the islets of the diabetic Biobreeding/Worcester rat. J Immunol. 1991;146:2990-2994.

75. Toyoda H, Formby B, Magalong D, et al. In situ islet cytokine gene expression during development of type I diabetes in the non-obese diabetic mouse. Immunol Lett. 1994;39:283-288.

76. Bendtzen K, Mandrup-Poulsen T, Nerup J, et al. Cytotoxicity of human pI 7 interleukin-1 for pancreatic islets of Langerhans. Science. 1986;232:1545-1547.

American Journal of Therapeutics (2005) 12(6) 
77. Eizirik DL, Tracey DE, Bendtzen K, et al. An interleukin1 receptor antagonist protein protects insulin-producing beta cells against suppressive effects of interleukin-1 beta. Diabetologia. 1991;34:445-448.

78. Hughes JH, Colca JR, Easom RA, et al. Interleukin 1 inhibits insulin secretion from isolated rat pancreatic islets by a process that requires gene transcription and mRNA translation. J Clin Invest. 1990;86:856-863.

79. Southern C, Schulster D, Green IC. Inhibition of insulin secretion by interleukin-1 beta and tumour necrosis factor-alpha via an L-arginine-dependent nitric oxide generating mechanism. FEBS Lett. 1990;276:42-44.

80. Eizirik DL, Mandrup-Poulsen T. A choice of death-the signal-transduction of immune-mediated beta-cell apoptosis. Diabetologia. 2001;44:2115-2133.

81. Corbett JA, Wang JL, Sweetland MA, et al. Interleukin 1 beta induces the formation of nitric oxide by beta-cells purified from rodent islets of Langerhans. Evidence for the beta-cell as a source and site of action of nitric oxide. J Clin Invest. 1992;90:2384-2391.

82. Corbett JA, Lancaster JR Jr, Sweetland MA, et al. Interleukin-1 beta-induced formation of EPR-detectable iron-nitrosyl complexes in islets of Langerhans. Role of nitric oxide in interleukin-1 beta-induced inhibition of insulin secretion. J Biol Chem. 1991;266:21351-21354.

83. Suarez-Pinzon WL, Szabo C, Rabinovitch A. Development of autoimmune diabetes in NOD mice is associated with the formation of peroxynitrite in pancreatic islet beta-cells. Diabetes. 1997;46:907-911.

84. Faust A, Kleemann $\mathrm{R}$, Rothe $\mathrm{H}$, et al. Role of macrophages and cytokines in $\beta$-cell death. In: Shafrir E, ed. Lessons From Animal Diabetes VI. Boston: Birhäuser; 1996: 47-56.

85. Asayama K, Kooy NW, Burr IM. Effect of vitamin E deficiency and selenium deficiency on insulin secretory reserve and free radical scavenging systems in islets: decrease of islet manganosuperoxide dismutase. J Lab Clin Med. 1986;107:459-464.

86. Kubisch HM, Wang J, Luche R, et al. Transgenic copper/zinc superoxide dismutase modulates susceptibility to type I diabetes. Proc Natl Acad Sci U S A. 1994;91: 9956-9959.

87. Kubisch HM, Wang J, Bray TM, et al. Targeted overexpression of $\mathrm{Cu} / \mathrm{Zn}$ superoxide dismutase protects pancreatic beta-cells against oxidative stress. Diabetes. 1997;46:1563-1566.

88. Piganelli JD, Flores SC, Cruz C, et al. A metalloporphyrinbased superoxide dismutase mimic inhibits adoptive transfer of autoimmune diabetes by a diabetogenic T-cell clone. Diabetes. 2002;51:347-355.

89. Burkart V, Wang ZQ, Radons J, et al. Mice lacking the poly(ADP-ribose) polymerase gene are resistant to pancreatic beta-cell destruction and diabetes development induced by streptozocin. Nat Med. 1999;5:314-319.

90. Ogawa M, Maruyama T, Hasegawa $T$, et al. The inhibitory effect of neonatal thymectomy on the incidence of insulitis in non-obese diabetes (NOD) mice. Biomed Res. 1985;6:103-106.
91. Christianson SW, Shultz LD, Leiter EH. Adoptive transfer of diabetes into immunodeficient NOD-scid/ scid mice. Relative contributions of $\mathrm{CD}^{+}$and $\mathrm{CD} 8^{+}$ T-cells from diabetic versus prediabetic NOD.NON-Thy1a donors. Diabetes. 1993;42:44-55.

92. Hayward AR, Shreiber M. Neonatal injection of CD3 antibody into nonobese diabetic mice reduces the incidence of insulitis and diabetes. J Immunol. 1989;143: 1555-1559.

93. Nagata M, Santamaria P, Kawamura T, et al. Evidence for the role of $\mathrm{CD}^{+}$cytotoxic $\mathrm{T}$ cells in the destruction of pancreatic beta-cells in nonobese diabetic mice. J Immunol. 1994;152:2042-2050.

94. Wong FS, Visintin I, Wen L, et al. CD8 T cell clones from young nonobese diabetic (NOD) islets can transfer rapid onset of diabetes in NOD mice in the absence of CD4 cells. J Exp Med. 1996;183:67-76.

95. Graser RT, DiLorenzo TP, Wang F, et al. Identification of a CD8 $\mathrm{T}$ cell that can independently mediate autoimmune diabetes development in the complete absence of CD4 T cell helper functions. J Immunol. 2000;164:39133918.

96. Kurrer MO, Pakala SV, Hanson HL, et al. Beta cell apoptosis in T cell-mediated autoimmune diabetes. Proc Natl Acad Sci U S A. 1997;94:213-218.

97. Serreze DV, Chapman HD, Varnum DS, et al. Initiation of autoimmune diabetes in NOD/Lt mice is MHC class I-dependent. J Immunol. 1997;158:3978-3986.

98. Nagata M, Yoon JW. Studies on autoimmunity for T-cellmediated beta-cell destruction. Distinct difference in beta-cell destruction between $\mathrm{CD}^{+}$and $\mathrm{CD}^{+}$T-cell clones derived from lymphocytes infiltrating the islets of NOD mice. Diabetes. 1992;41:998-1008.

99. Verdaguer J, Yoon JW, Anderson B, et al. Acceleration of spontaneous diabetes in TCR-beta-transgenic nonobese diabetic mice by beta-cell cytotoxic CD8+ $\mathrm{T}$ cells expressing identical endogenous TCR-alpha chains. J Immunol. 1996;157:4726-4735.

100. Verdaguer J, Schmidt D, Amrani A, et al. Spontaneous autoimmune diabetes in monoclonal $\mathrm{T}$ cell nonobese diabetic mice. J Exp Med. 1997;186:1663-1676.

101. Rabinovitch A, Suarez-Pinzon WL. Role of cytokines in the pathogenesis of autoimmune diabetes mellitus. Rev Endocr Metab Disord. 2003;4:291-299.

102. Debray-Sachs M, Carnaud C, Boitard C, et al. Prevention of diabetes in NOD mice treated with antibody to murine IFN gamma. J Autoimmun. 1991;4:237248.

103. Sarvetnick N, Liggitt D, Pitts SL, et al. Insulin-dependent diabetes mellitus induced in transgenic mice by ectopic expression of class II MHC and interferon-gamma. Cell. 1988;52:773-782.

104. Hultgren B, Huang X, Dybdal N, et al. Genetic absence of gamma-interferon delays but does not prevent diabetes in NOD mice. Diabetes. 1996;45:812-817.

105. Cameron MJ, Arreaza GA, Zucker P, et al. IL-4 prevents insulitis and insulin-dependent diabetes mellitus in nonobese diabetic mice by potentiation of regulatory 
T helper-2 cell function. J Immunol. 1997;159:46864692.

106. Pennline KJ, Roque-Gaffney E, Monahan M. Recombinant human IL-10 prevents the onset of diabetes in the nonobese diabetic mouse. Clin Immunol Immunopathol. 1994;71:169-175.

107. Mueller R, Krahl T, Sarvetnick N. Pancreatic expression of interleukin- 4 abrogates insulitis and autoimmune diabetes in nonobese diabetic (NOD) mice. J Exp Med. 1996;184:1093-1099.

108. Wang B, Gonzalez A, Hoglund P, et al. Interleukin-4 deficiency does not exacerbate disease in NOD mice. Diabetes. 1998;47:1207-1211.
109. Itoh N, Imagawa A, Hanafusa T, et al. Requirement of Fas for the development of autoimmune diabetes in nonobese diabetic mice. J Exp Med. 1997;186:613-618.

110. Apostolou I, Hao Z, Rajewsky K, et al. Effective destruction of Fas-deficient insulin-producing beta cells in type 1 diabetes. J Exp Med. 2003;198:1103-1106.

111. Kurrer MO, Pakala SV, Hanson HL, et al. Beta cell apoptosis in T cell-mediated autoimmune diabetes. Proc Natl Acad Sci U S A. 1997;94:213-218.

112. Kagi D, Odermatt B, Seiler $P$, et al. Reduced incidence and delayed onset of diabetes in perforin-deficient nonobese diabetic mice. J Exp Med. 1997;186:989997. 